https://doi.org/10.48009/1_iis_2008_241-248

\title{
CIS MINORS IN THE U.S.: AN ANALYSIS OF EXISTING CURRICULA
}

\author{
Lissa Pollacia, pollacia@nsula.edu \\ William Lomerson, lomersonw@nsula.edu \\ Jack Russell, jrussell@nsula.edu
}

\begin{abstract}
The number of U.S. students who choose Computer Information Systems (CIS), Management Information Systems (MIS), or Computer Science (CS) as a major has declined significantly in the last seven years. For many computing departments, it is imperative to seek ways to increase the number of enrollments. One such option is to develop and offer a new type of multi-disciplinary minor that incorporate computercentric courses taught by CIS and other departments throughout the university. This paper describes a review of CIS minors offered at institutions in the U.S. The results of the review focus on information such as the type of minor, the number of credit hours, and the types of courses that are required. It is our hope that this study will provide information to assist a department considering curriculum changes.
\end{abstract}

Keywords: CIS Minors, Computer majors, Enrollment, CIS Curricula

\section{INTRODUCTION}

All evidence indicates that the number of students who are electing to major in science, technology, engineering, and mathematics (STEM) disciplines has declined dramatically since the year 2000 . Particularly hard hit are all computing-related fields, such as Computer Information Systems (CIS), Computer Science (CS), and Management Information Systems (MIS) [5, 7]. After six years of steady declines, the number of new CS majors in Fall 2006 was only half of what it was in the Fall of 2000 [16]. The decrease in computing enrollments coupled with a large number of pending retirements is expected to result in a substantial shortage of skilled workers in the U.S. in the next few years [2, 9].

Recent studies show that there are a variety of reasons for this decline, such as students' inaccurate perception of the computing profession, particularly with respect to job prospects and career opportunities. Other reasons cited are the dot com bust, the outsourcing of jobs overseas, the decline in students' analytical abilities, and the perception of "geek"/"nerd" for computer professionals. A large number of students indicated that they think the work will be too hard or technical $[7,13]$.
The question facing many CIS programs is: what measures can be taken to improve this situation? Some computing programs are beginning to examine ways to provide course offerings to a wider audience of students. One way to do this is by increasing the number of service courses that are used to fulfill basic electives or core requirements. Another option is the introduction of CIS minors for students who are not CIS majors. This can involve the development of a multi-disciplinary minor, offered in partnership with other departments throughout the university.

The CIS department within the authors' institution, Northwestern State University, recently embarked on the development of this type of multi-disciplinary minor. As part of the process, we conducted a review of minors offered in CIS at colleges and universities in the United States. We wanted to determine if other institutions had developed similar offerings, and if so, what were the characteristics of the minor. We found that a CIS minor may also be known by other names, such as Information Systems (IS), Information Technology (IT), Computing Sciences and so forth. However, the overwhelming majority are called CIS, therefore in this paper we will use CIS to refer to this list of titles collectively.

We collected data concerning the type of minor (whether it was traditional or multi-disciplinary), the number of total credit hours required, and the types of courses that are generally included. We then analyzed this data to determine commonalities and differences in these minors. The most innovative of the multi-disciplinary minors are described. It is the author's hope that this study will provide information to faculty who may be considering curriculum changes, particularly with respect to minor degree programs.

\section{REASONS FOR THE DECLINE}

In a recent survey of faculty at U.S. universities that offer a bachelors degree in Computer Information Systems, Management Information Systems, or Information Technology [6], seventy-six (76.1\%) of the respondents reported that enrollment had decreased in the past two years. When questioned about the reasons as to why they felt that enrollment had declined at their institutions, sixty-seven (67\%) blamed the outsourcing of jobs, sixty (60\%) stated 
the economy in general, sixty (60\%) cited the dot com failure, forty (40\%) indicated that the drop was cyclical in nature, and twenty-seven (27\%) stated it was due to decline in students' analytical abilities.

The author's own recent research has provided some information concerning the cause for the enrollment decline [7, 13]. In a survey of students in introductory computer literacy courses, many of the students reported that they did not choose a computer-related career due to inaccurate or insufficient information concerning computing careers. The results also show that students have a high level of dissatisfaction with their high school counseling experience, and received little or no guidance, particularly with respect to the computing profession. Other reasons cited were the lack of interest in a computer-related profession; they did not think they would like the work; they thought the work would be too hard; or they did not think that there were very many jobs available in this field.

A related study produced very similar results. Respondents in this study were business students in introductory business classes. The respondents indicated that they were knowledgeable about careers in management, marketing, accounting, and finance; and were least knowledgeable about information systems. To sum it up: "This generation, which is noted for its pervasive use of technology, has little interest in, or awareness of, the occupations that drive the digital age" [3].

\section{PERCEPTIONS VS. REALITY}

In actuality, students' perceptions of career opportunities are not aligned with reality. The majority of students have poor information and misconceptions about nearly every aspect of the profession. According to the U.S. Department of Labor, high-level jobs that combine technical and business skills are still abundant in the U.S. The Bureau of Labor Statistics projects that the number of jobs in the industry sector Computer Systems Design And Related Services, will increase by $54.6 \%$ from 2002 to 2012 [1]. In fact, the bureau predicts that eight of the eleven fastest-growing occupations through 2012 that require a bachelor's degree will be in this sector.

Other employment analysts write that the hiring in information systems is slated for continued growth [4, 12]. MONEY Magazine and Salary.com, a leading provider of employee compensation data and software, researched hundreds of jobs and compiled a list of the "Top 10 Best Jobs in America" [8]. Software engineer was rated as the number one job; with "Computer IT Analyst" at number 7. The criteria for rating the jobs included projected job growth, annual salary, work environment, annual job openings, stress levels, flexibility in hours, creativity, and the opportunities for advancement in the field.

The reality is that the area of information systems is one of the fastest growing areas of employment, with high salaries and earning potential. Two of the 10 most highly rated jobs are in this area. Therefore we need to educate potential students to see information systems as an energetic and growing profession, with outstanding long-term job security, salary prospects, and prestige.

\section{RECRUITING IN PLACE}

What can we do to increase our enrollments? One of the low-cost measures that a CIS department may undertake is "recruiting in place". This is a term that we have coined to describe activities to increase enrollments by recruiting students who are already enrolled at our own institution.

When the authors first begin thinking about providing more offerings for non-majors, it required a shift in our thinking as we were generally focused only on CIS majors. We began to become more aware of the inter-disciplinary nature of computing, and tried to develop ways to collaborate with other disciplines on our campus. Once we embraced this idea of recruiting in place, and we found that the most direct path to enticing students to take more CIS courses was to offer a minor that would enhance the student's own chosen field of study.

As a result, we recently instituted a new CIS minor that includes courses from Art, Mathematics, and the University Library. The new CIS minor consists of six courses (18 hours). Three of the courses are required to be CIS; one required course is offered through the university library; the other two electives may be additional CIS courses; Computer Science courses (offered by the Math department) or graphics art/ web design courses (offered by the Art Department) [14].

The CIS courses have been developed specifically for the minor, and are at a level appropriate for students who are not CIS majors. These courses are Introduction to Applications Programming, Introduction to Database Systems, Multi-Media Communication and Presentation, and Introduction to Information Systems. The Library course focuses on Information Sources and Services, and is designed to teach students to utilize the digital library to search for and evaluate information. The library staff was very pleased with the opportunity to create and offer this type of course. This is the first course ever 
offered by our institution's library. The curriculum went into effect at the beginning of the Spring 2008 semester.

\section{CIS MINOR}

As previously stated, we discovered that a CIS minor may be known by other names, such as Information Systems or Information Technology. The number of credit hours and curriculum of a CIS minor is different for virtually every institution. The majority of the CIS minors are what we call traditional. The traditional CIS minor is essentially a scaled-down version of the CIS major, with all of the required classes coming from the CIS department, and the majority of courses are those that are taken by CIS majors.

We also defined two other categories of CIS minors: composite and multi-disciplinary. The composite minor is one where a majority of the courses are from the CIS department; however the student also takes courses from one other major area within the institution to complete the degree. For example, a CIS minor that also permitted Art electives in web design and development would be a composite minor.

We use the term multi-disciplinary to designate minors that focus on the study of information technology through its application in a variety of different fields. Departments offering computercentric courses may include art, computer science, English, journalism, biology, and so forth. Generally a required number of courses must be taken from the computing department before the student takes elective courses from the other departments. However, the student has some flexibility when choosing electives, and therefore may tailor a program that suits his/her own interests.

The IT minor at the University of North Carolina Wilmington is an example of a multi-disciplinary minor [10]. Requirements consist of 3 computer science courses, i.e. Fluency of Information Technology, an introductory programming course, and one other computer science course of the student's choosing. There is an additional required course offered by the university library, similar to the Information Sources and Services course described above. The remaining two courses may be selected from computer-centric courses offered by other departments: Art, Chemistry, Communications, Educational Technology, English, Film Studies, GIS, Music, Logic, and Sociology.

\section{METHODOLOGY}

The authors collected data about CIS minors that are offered in U.S. colleges and universities. The data was gathered using an Internet search and also through a search of directories (College Blue Book, American Universities and Colleges, Patterson's American Education) and databases (ERIC, Professional Development Collection in Education, Business Source Premier, Computer Science Index, Computer Source, Information Science and Technology Abstracts). This search revealed that there is no compiled listing of minors in CIS.

The keywords used for the Internet search were: "minors", "Computer Information Systems" and "Information Technology". We found 137 institutions that offer a minor, and from which we could locate relevant information.

We compiled the following information about each minor: the name of the institution, the name of the minor, category (Traditional, Composite, or Multidisciplinary), the number of credit hours, the number of elective credit hours, and any special requirements. In addition, we reviewed the courses that constituted the curriculum. The following generic course titles are those that were listed most often: 1) Introduction to Information Technology, 2) Programming I, 3) Management Information Systems, 4) Database Systems, 5) Systems Analysis and Design, 6) Web Development/Design, and

Telecommunications/Networks.

The raw data was initially collected into a spreadsheet. Pivot tables were used to cross tabulate most of the results found in the section below. Pearson Chi Square was used in testing the statistical significance related to the hypotheses listed in the section "Testing the Null Hypotheses."

\section{RESULTS OF THE STUDY}

Nineteen (19) different minor titles were discovered from the computer search. Only three (3) titles, CIS, Information Technology (IT) and Information Systems (IS), emerged with a significant frequency distribution and were chosen as the primary titles for this study. There were ninety-two (92) programs with the title of CIS, fifteen (15) with the title of Information Technology (IT) and nine (9) with the title of Information Systems (IS). The remaining twenty-one titles were grouped analyzed using the title of Other. This provided a survey sample of 137 curricula.

The term "Minor Title" will be used to reference CIS, IT, IS or Other. The term "Minor Category" will be 
used to denote Traditional, Composite or Multidisciplinary.

\section{Research Questions:}

The authors developed a series of research questions that focus on discovering the general characteristics of these minors by examining the types of courses and number of credit hours among either the Minor Title or the Category (Traditional, Composite, and Multi-disciplinary). The following research questions are:

1. How similar or different are the average number of credit hours and elective hours among the Minor Titles (CIS, IT, IS or Other)?
2. How similar or different are the average number of credit hours and elective hours among the Minor Categories (Traditional, Composite or Multi-disciplinary)?

3. What was the distribution of Traditional, Composite or Multi-disciplinary minors among the different Minor Titles (CIS, IT, IS or Other)?

4. What was the distribution of the common courses listed in the previous section among the Minor Titles and Minor Categories?

\section{Research Question 1}

Table 1 below presents the analysis of total and elective hours among the Minor Titles (CIS, IS, IT or Other).

\begin{tabular}{|l|l|l|l|l|l|l|l|l|l|}
\hline \multirow{2}{*}{ Minor Title } & \multicolumn{3}{|l|}{ Total Hours } & \multicolumn{2}{l|}{ Elective Hours } & \multirow{2}{*}{ Count } & $\begin{array}{l}\text { Per Cent } \\
\text { of Total }\end{array}$ \\
\cline { 2 - 10 } & Average & Max & Min & Average & Max & Min & & 62 & $67 \%$ \\
\hline CIS & 19.2 & 30 & 12 & 6.2 & 18 & 0 & 92 & $11 \%$ \\
\hline $\begin{array}{l}\text { Information } \\
\text { Technology }\end{array}$ & 18.5 & 27 & 15 & 6.3 & 12 & 0 & 15 & $7 \%$ \\
\hline $\begin{array}{l}\text { Information } \\
\text { Systems }\end{array}$ & 20.2 & 30 & 15 & 4.8 & 12 & 0 & 9 & $7 \%$ \\
\hline Other & 19.8 & 32 & 15 & 6.4 & 15 & 0 & 21 & $15 \%$ \\
\hline Cumulative & 19.3 & 32 & 12 & 6.2 & 18 & 0 & 137 & \\
\hline
\end{tabular}

Table 1. Average Degree and Elective Hours for Minor Titles

This analysis shows that all minors are relatively similar with the averages ranging from 18.5 to 20.2 hours and an overall average of 19.3 hours. The range of total hours, however, is surprisingly large, running from 12 hours to 32 hours. The Elective hours are also relatively similar with the averages ranging from 4.8 to 6.2 hours with an overall average of 6.2. The range of elective hours was also large, running from 0 hours to 18 hours.

\section{Research Question 2}

Table 2 below presents a comparison of the average credit hours and elective credit hours by Minor Category (Traditional, Composite and Multidisciplinary). This analysis shows that the degrees remain very similar in total hour requirements with a range of 18.7 to 19.8 hours. The cumulative data is redisplayed to facilitate continuity of analysis when studying the tables.

\begin{tabular}{|c|c|c|c|c|c|c|c|c|}
\hline \multirow{2}{*}{$\begin{array}{l}\text { Minor } \\
\text { Category }\end{array}$} & \multicolumn{3}{|c|}{ Minor Hours } & \multicolumn{3}{|c|}{ Elective Hours } & \multirow{2}{*}{ Count } & \multirow{2}{*}{$\begin{array}{l}\text { Per Cent } \\
\text { of Total }\end{array}$} \\
\hline & Average & Max & Min & Average & Max & Min & & \\
\hline Traditional & 19.3 & 32 & 12 & 6.1 & 18 & 0 & 109 & $80 \%$ \\
\hline Composite & 19.8 & 24 & 15 & 4.9 & 18 & 0 & 17 & $12 \%$ \\
\hline $\begin{array}{l}\text { Multi- } \\
\text { Disciplinary }\end{array}$ & 18.7 & 30 & 15 & 8.8 & 18 & 0 & 11 & $8 \%$ \\
\hline Cumulative & 19.3 & 32 & 12 & 6.2 & 18 & 0 & 137 & \\
\hline
\end{tabular}

Table 2. Average Degree and Elective Hours for Minor Categories 
The Multi-Disciplinary category has about 50\% more elective hours (8.8) than the other two categories, which is to be expected as this minor would generally target a broader academic audience that required a more varied selection of courses.

The Traditional (6.1 hours) and Composite (4.9 hours) minors offer fewer electives, which is also expected since they tend to be designed to provide more narrowly focused courses of study. The Composite degree offers the least number of electives, which is probably the result of multiple departments who each specifies its own required content thereby leaving fewer hours remaining for electives.

\section{Research Question 3}

Table 3 and Table 4 below present cross tabulations of the distribution of Minor Categories within the
Minor Titles. Table 3 displays the distribution of Minor Categories within each Minor Title as a per cent based upon the number of minors within that Minor Title; this presentation enables comparison of the differences in the categories offered by the title areas. Table 4 displays the distribution of minors as a per cent based upon the total number of minors offered.

Table 3 shows that CIS and Information Systems areas are still predominately traditional in the structure of their minor offerings. Information Technology and Other, however, appear to be moving more rapidly into non traditional offerings with one-third (33\%) of the minors in these areas classified as Composite or Multi-Disciplinary. Information Technology as made the strongest move to obtain external students with $27 \%$ of its minors classified as Multi-Disciplinary.

\begin{tabular}{|l|l|l|l|l|}
\hline Minor & Categories & \multicolumn{3}{|l|}{} \\
\hline Title & Traditional & Composite & $\begin{array}{l}\text { Multi- } \\
\text { Disciplinary }\end{array}$ & $\begin{array}{l}\text { Number of } \\
\text { Minors }\end{array}$ \\
\hline CIS & $85 \%$ & $12 \%$ & $3 \%$ & 92 \\
\hline $\begin{array}{l}\text { Information } \\
\text { Technology }\end{array}$ & $67 \%$ & $7 \%$ & $27 \%$ & 15 \\
\hline $\begin{array}{l}\text { Information } \\
\text { Systems }\end{array}$ & $78 \%$ & $11 \%$ & $11 \%$ & 9 \\
\hline Other & $67 \%$ & $19 \%$ & $14 \%$ & 21 \\
\hline
\end{tabular}

Table 3: Per Cent of Minor Categories within Minor Titles

Table 4 shows that $80 \%$ of the minors offered still follow the traditional format, which in most instances is simply a scaled down version of the major. The Composite and Multi-Disciplinary offerings indicate an attempt to recognize that the IS areas have the potential to enhance the understanding and incorporation of its concepts and methodologies beneficially into other disciplines in ways that allow students to deviate from the relatively rigid Traditional course offerings.

\begin{tabular}{|l|l|l|l|l|}
\hline Minor & Categories & \multicolumn{3}{l|}{} \\
\hline Title & Traditional & Composite & $\begin{array}{l}\text { Multi- } \\
\text { Disciplinary }\end{array}$ & $\begin{array}{l}\text { Per Cent Of } \\
\text { Total }\end{array}$ \\
\hline CIS & $57 \%$ & $8 \%$ & $2 \%$ & $67 \%$ \\
\hline $\begin{array}{l}\text { Information } \\
\text { Technology }\end{array}$ & $7 \%$ & $1 \%$ & $3 \%$ & $11 \%$ \\
\hline $\begin{array}{l}\text { Information } \\
\text { Systems }\end{array}$ & $5 \%$ & $1 \%$ & $1 \%$ & $7 \%$ \\
\hline Other & $10 \%$ & $3 \%$ & $2 \%$ & $15 \%$ \\
\hline Cumulative & $80 \%$ & $12 \%$ & $8 \%$ & \\
\hline
\end{tabular}

Table 4: Minor Categories within Minor Titles as a Per Cent of Total Minors 


\section{Research Question 4}

Tables 5 and 6 display the frequency with which the common set of courses described earlier in the paper appear within the minors examined in this study.
Table 5 displays the distribution within the Minor Titles classification and Table 6 displays the course distributions with the Categories classification. The per cent is based upon the number of minors within each class.

\begin{tabular}{|l|l|l|l|l|l|}
\hline & \multicolumn{4}{|l|}{ Minor Title } & Combined \\
\hline Courses & CIS & $\begin{array}{l}\text { Information } \\
\text { Technology }\end{array}$ & $\begin{array}{l}\text { Information } \\
\text { Systems }\end{array}$ & Other & $\begin{array}{l}\text { Per Cent } \\
\text { of Total }\end{array}$ \\
\hline Programming 1 & $83 \%$ & $73 \%$ & $56 \%$ & $62 \%$ & $77 \%$ \\
\hline Database Systems & $52 \%$ & $47 \%$ & $44 \%$ & $43 \%$ & $50 \%$ \\
\hline Systems Analysis \& Design & $45 \%$ & $40 \%$ & $67 \%$ & $43 \%$ & $45 \%$ \\
\hline Introduction to IT & $41 \%$ & $53 \%$ & $78 \%$ & $19 \%$ & $42 \%$ \\
\hline Web Design/Development & $25 \%$ & $53 \%$ & $33 \%$ & $48 \%$ & $32 \%$ \\
\hline Data Communications & $30 \%$ & $27 \%$ & $22 \%$ & $38 \%$ & $31 \%$ \\
\hline Mgt Information Systems & $28 \%$ & $27 \%$ & $11 \%$ & $14 \%$ & $25 \%$ \\
\hline
\end{tabular}

Table 5. Per Cent of Minor Titles Offering Common Course Titles

\begin{tabular}{|l|l|l|l|l|}
\hline & \multicolumn{2}{|l|}{ Minor Categories } & Combined \\
\hline Courses & Traditional & Composite & $\begin{array}{l}\text { Multi- } \\
\text { Disciplinary }\end{array}$ & $\begin{array}{l}\text { Per Cent of } \\
\text { Total }\end{array}$ \\
\hline Programming 1 & $80 \%$ & $76 \%$ & $45 \%$ & $77 \%$ \\
\hline Database Systems & $55 \%$ & $41 \%$ & $9 \%$ & $50 \%$ \\
\hline Systems Analysis \& Design & $47 \%$ & $53 \%$ & $18 \%$ & $45 \%$ \\
\hline Introduction to IT & $43 \%$ & $35 \%$ & $36 \%$ & $42 \%$ \\
\hline Web Design/Development & $30 \%$ & $35 \%$ & $45 \%$ & $32 \%$ \\
\hline Data Communications & $35 \%$ & $24 \%$ & $0 \%$ & $31 \%$ \\
\hline Mgt Information Systems & $26 \%$ & $24 \%$ & $18 \%$ & $25 \%$ \\
\hline
\end{tabular}

Table 6. Per Cent of Minor Categories Offering Common Course Titles

The data in Table 5 highlights a surprising lack of common courses with in the minors. Only two courses, Programming and Database Systems appear in half or more of the minors.
In Table 6, the data shows that the Multi-Disciplinary minor has moved well away from the traditional course offerings with 4 courses appearing in only $20 \%$ or less of these minors with remainder showing up in $45 \%$ or less of these minors.

\begin{tabular}{|l|l|l|l|l|l|l|l|l|}
\hline Number of Core Offerings & 0 & 1 & 2 & 3 & 4 & 5 & 6 & \\
\hline Number of Minor Programs & 1 & 2 & 12 & 14 & 10 & 10 & 6 & 55 \\
\hline Per Cent of Minor Programs & $2 \%$ & $4 \%$ & $22 \%$ & $25 \%$ & $18 \%$ & $18 \%$ & $11 \%$ & \\
\hline Cumulative Per Cent & $2 \%$ & $6 \%$ & $28 \%$ & $53 \%$ & $71 \%$ & $89 \%$ & $100 \%$ & \\
\hline
\end{tabular}

Table 7. Frequency of Core Offerings in Minor Programs

Table 7 highlights the fact that the core offerings are not very universal. Only $47 \%$ of the minor programs included 4 or more of the core offerings. This indicates that over $50 \%$ of the minors offer at least $50 \%$ of the courses outside of the core offerings. 


\section{CONCLUSIONS}

For several years now, U.S. colleges and universities have seen a steady decline in students majoring in STEM disciplines, particularly in computer-related fields. While there are a variety of reasons for this decline, much of the problem stems from misinformation or lack of information concerning the discipline, career opportunities, nature of the work, and concern of the outsourcing of jobs overseas.

One of the ways to address this decline in enrollments is "recruiting in place", which we define to be recruitment of students who are already on campus. During the process of developing a CIS minor for non-majors, we collected data to determine what types of CIS minors are currently being offered by U.S. institutions. We found that, for the institutions that we examined, the overwhelming majority of CIS minors are traditional, meaning that all courses in the curriculum are CIS courses. A small percentage of those reviewed were composite minors, which means the CIS department partners with one other department. A small number of minors were classified as multi-disciplinary, where the courses that comprise the minor may come from a cross section of disciplines.

In examining the course offerings within the minors, we found that there are some commonalities concerning the courses included in the curriculum. The most commonly included classes were Introduction to Programming, Database Systems, and Introduction to Information Technology. The number of course credits required to complete the minor ranged from 15 to 30, with the average being approximately 19 credits, with 8 credits of electives.

This study is the first step taken by our CIS department to recruit more students on our own campus. We wanted to determine what other institutions were doing with respect to offering minors. We had hoped to find more multidisciplinary minors that we could use as a model for developing one for our own campus.

Future work will include a more thorough examination of those institutions that offer multidisciplinary bachelor's degrees, such as those offered by the University of California at Berkeley and Georgia Institute of Technology [2]. We feel that by increasing our focus to include bachelor's degrees, we will develop insight into how a program can link technology, business, and other disciplines.

\section{REFERENCES}

1. Bureau (2006) Occupational Outlook Handbook, 2006-07 Edition, Bureau of Labor Statistics, U.S. Department of Labor, retrieved from the Bureau of Labor Statistics web site on 1/4/2007: http://www.bls.gov/oco/oco2003.htm.

2. Business Week “A Red Flag in the Brain Game”, Business Week, May 1, 2006. Retrieved from: http://www.businessweek.com/magazine/content /06_18/b3982053.htm on 2/26/2008.

3. Crampton, William J., Walstrom, Kent A., and Schambach, Thomas P. (2006, October) "Factors Influencing Major Selection by College of Business Students", Issues in Information Systems, October 2006, International Association for Computer Information Systems, Vol. VII(1), 2006, p. 226-230.

4. Fisher, Annie. "Hottest College Degrees for Getting Hired”. Fortune, Sept. 8, 2006. Retrieved from: http://money.cnn.com/2006/09/07/news/econom y/hottest.majors.fortune/index.htm. on 1/4/2007.

5. Kessler, Michelle (2005, May 23) Fewer Students Major in Computer: Some Fear Shortage of U.S. Workers, More Outsourcing. USAToday, retrieved from USAToday web site on 7/12/2005: www.usatoday.com/printedition/money/2005052 3/1b_computerscience23.art.htm.

6. Lenox, Terri L., Charles R. Woratschek, and Gary A. Davis (2005, October) "Exploring Declining CS/IS/IT Enrollments”, Proceedings of ISECON 2005, v22, Columbus, OH, Oct. 2005.

7. Lomerson, William and Pollacia, Lissa. (2005, October) "Declining CIS Enrollment: An Examination of Pre-College Factors". Proceedings of ISECON 2005, v22, Columbus, OH, Oct. 2005.

8. Money (2006, January) Top 10 Best Jobs in America. Retrieved from CNNMoney.com website on 1/3/2007: http://money.cnn.com/magazines/moneymag/bes tjobs/.

9. Murphy, Chris (2005, October) "Speak Up for the IT Career”. InformationWeek, Oct. 3, 2005, retrieved from www.informationweek.com/shared/printableArti cleSrc.jhtml?articleID=171202135 on 2/27/2006.

10. Patterson, David A. (2005, September) "Restoring the popularity of Computer Science", 
Communications of the ACM, Vol. 48, Issue 9, Sept. 2005, pages 25-28.

11. Patterson, Laurie J. (2005, June) "Reaching a New Audience: Development of ComputerCentric Minor", Proceedings 2005 ASCUE Conference, Myrtle Beach, South Carolina, www.ascue.org.

12. Paulson, Linda Dailey. (2006, September) "IT Hiring Growth Modest, But Steady," IT Professional, vol. 08, no. 1, pp. 6-9, Jan/Feb, 2006.

13. Pollacia, Lissa and Lomerson, William. (2006, October) "Analysis of factors affecting declining CIS enrollment”, Issues in Information Systems, October 2006, International Association for Computer Information Systems Vol. VII(1), 2006, p. 220-225.

14. Russell, Jack, Russell, Barbara, and Pollacia, Lissa. (2008, March) "Reversing the Decline of CIS Enrollment in Colleges and Universities by Creating Viable and Attractive Minors in CIS: A Statistical Study of CIS Minors at US Colleges and Universities", Information Systems Education Journal, accepted for publication.

15. Vegso, Jay (2005, May) "Interest in CS as a Major Drops among Incoming Freshmen". Computing Research News, Vol. 17/No. 3, May 2005.

16. Vesgo, Jay (2007, March) "Continued Drop in CS Bachelor's Degree Production and Enrollments as the Number of New Majors Stabilizes", Computing Research News, Vol. 19/No. 2, March 2007. 